\title{
FLANDES, PORTUGAL Y TOLEDO EN LA OBRA DE LUIS DE MORALES: LAS VÍRGENES GITANAS O DEL SOMBRERO
}

\author{
POR \\ ISABel MATEO Gómez \\ Instituto de Historia, CSIC
}

Se trata de profundizar un poco más en las diversas influencias pictóricas que formaron el estilo de Luis de Morales subrayando que fueron, en este orden, las escuelas flamenca, portuguesa y toledana, las más importantes. Se dan a conocer tablas de Morales inéditas y se sugiere el origen de la iconografía de las Vírgenes del sombrero o gitanas.

Palabras Clave: Morales; Formación; Virgen del sombrero; Inéditos

A attempt is made to deepen our understanding of the diverse pictorial influences that went into the formation of the style of Luis de Morales: emphasis is placed on the Flemish, Portuguese and Toledan schools. Unpublished panel paintings are presented and suggestions are offered for the source of the iconography of the Virgins of the Hat or gypsies.

KeY words: Morales, Formation, Virgin of the Hat, unpublished.

El pintor extremeño Luis de Morales es considerado desde sus primeros biógrafos como un pintor singular dentro del panorama pictórico español de la segunda mitad del siglo XVI. Todos los autores coinciden, en considerarle, también, más que como un pintor de retablos como un autor dedicado a cuadros de devoción -sobre todo en aquellos referentes a la Pasión- y, desde luego éstos de una iconografía no demasiado variada. A pesar de ello, la clientela fue importante no sólo en cantidad sino en categoría social, dando lugar a que el pintor creara un taller de importante calidad para dar respuesta a los numerosos encargos que se le hacían.

Luis de Morales desarrolló su actividad artística en Badajoz, ciudad donde debió nacer. Tomando como base a Jusepe Martínez, se le entronca con unos "Morales" de ascendencia sevillana, sin embargo, nuevos datos documentales aportados por su último estudioso, don Carmelo Solís, canónigo de la catedral de Badajoz, hacen proceder a la familia de Salamanca ${ }^{1}$.

1 D. Angulo, "La Pintura del siglo XVI" en Ars Hispaniae, vol. XII, Madrid, 1954, p. 231; F. MARIAS, El largo siglo XVI, Madrid, 1989, p. 340; C. SOLIS, Luis de Morales, Badajoz, 2000. 
Respecto a la fecha de nacimiento creemos la más acertada la propuesta por Gaya Nuño, quien le supone nacido en Badajoz, más o menos hacia el año $1520^{2}$. Aceptando esta fecha podrían explicarse algunos aspectos de su obra que conciernen a su formación artística y que no han sido muy destacados, como por ejemplo, la influencia de artistas del foco toledano que en la década de los cuarenta se hallaban en pleno éxito de su carrera.

No cabe duda de que la pequeña monografía que sobre Morales escribió Gaya Nuño, ofrece un planteamiento serio y sugerente sobre la sensibilidad del pintor y de su obra, debiéndose considerar que su estudio está todavía vigente pese a los muchos años transcurridos desde su publicación. Sus intuiciones se han ido confirmando en estudios posteriores de la pintura del XVI español, ayudando, también, a puntualizar aspectos sobre el pintor extremeño ${ }^{3}$.

La situación geográfica de Badajoz, próxima a Sevilla y Portugal, y el mecenazgo que el arzobispo de Badajoz, don Juan de Ribera, ejerció sobre el pintor, han sido determinantes para suponerle a Morales una formación o estancia larga en dichos lugares. Nadie como Gaya Nuño definió su estilo al considerarle como un artista "curioso de modalidades ajenas" y de "una receptividad curiosamente virgen y desnuda"4. De ello se deduce que la formación del pintor, cuyo estilo no está determinado por la presión o admiración hacia un maestro determinado, fue la de un autodidacta que estudió y absorbió a los más importantes artistas anteriores a él y a sus contemporáneos más importantes próximos a él. Este aprendizaje lo puso al servicio de una pintura de íntima religiosidad que sin duda gustaba a la sociedad de su tiempo y que, con distinto matiz de expresión, tenía sus raíces en la lejana iconografía religiosa de los primitivos flamencos. Gaya Nuño lo señaló y, desde luego, no hay nada más que comparar la composición en vertical de la Piedad de Morales, de la Academia de San Fernando de Madrid, con la del mismo tema interpretada por Memling, de la Capilla Real de Granada. (Figs. 1-2).

En general, los autores que han estudiado a Morales consideran que en sus obras se mezclan la inspiración personal y los citados contactos con Sevilla y Portugal, a los que habría de sumarse la de los romanistas y manieristas flamencos y la de los italianos de los que existían obras en España ${ }^{5}$. En algunos casos se concretan nombres que pudieron haber influido en él: los sevillanos Vargas y Campaña, el portugués fray Carlos, el flamenco Gossaert y los italianos Piombo y Beccaffumi, amén de lo leonardesco centrado en la figura de Luini.

Si damos por buena la fecha de 1520, como la de su nacimiento, su periodo de formación debió comenzar hacia el año 1535. En ese año, y sin descartar las posibles influencias citadas, no se ha valorado suficientemente la importancia que por esos años mantenía la escuela toledana, bajo la sede episcopal del cardenal Tavera. Tampoco se han considerado los contactos familiares del arzobispo Ribera con Toledo, a través de los Afán de Rivera y de Teresa Enríquez, "la loca del Sacramento", teniendo en cuenta, además, la vinculación de Badajoz con la diócesis de Toledo. En la ciudad imperial destacaba por esos años Juan Correa de Vivar, quien, sobre un sustrato flamenco heredado de Borgoña, comenzaba a introducir en sus obras un rafaelismo con cierta "cadencia"

\footnotetext{
2 Gaya Nuño, Luis de Morales, Madrid, 1961, p. 9. Este autor rechaza las de 1509 o 1510 sugeridas por Palomino; MARIAS, loc. cit. nota 1, sugiere como fecha de nacimiento el año 1515.

3 GAYA NuÑo, loc. cit. nota 2, p. 30 y 22.

${ }^{4}$ Loc. cit. nota 3, p. 10, 30. Este autor apunta, también, los pocos recursos iconográficos del pintor, p. 16.

5 V. SAmbricio, "En torno al Divino Morales", Boletín del Seminario de Arte y Arqueología de Valladolid, 1942, p. 131-141; E. Du GuÉ TraPier, Luis de Morales and Leonardesque influences in Spain, New Cork, 1951; D. Angulo, "La pintura del siglo XVI", Ars Hispaniae, vol. XII, Madrid, 1954, p. 231-246; J. A. GAYA NuÑo, Luis de Morales, Madrid, 1961; I. BÄCKSBACKA, Luis de Morales, Helsinki, 1962; J. CAMÓn AZnAR, "La pintura española del siglo XVI", Summa Artis, vol. XXIV, Madrid, 1970, p. 459-483; F. Marías, El largo siglo XVI, Madrid, 1989, p. 340-349; F. BENITO, "La pintura española desde el pleno Renacimiento al Manierismo", Pintura Española, Tomo I, Milán, 1995, p. 256-257. La afición y sensibilidad íntima de la pintura de Morales, le hace ser un pintor más cercano a las pequeñas tablas y a los trípticos -de origen flamenco- que a un pintor de retablos, de clara estirpe española.
} 
manierista, y la utilización del grabado, tanto flamenco como italiano, para sus composiciones. Características que también se observa en la obra de Morales. El sentido piadoso de la pintura toledana de la segunda mitad del siglo XVI arranca de Juan de Borgoña y, por lo tanto, conecta con la piedad intimista transmitida por Morales. Recordemos que en la década de los treinta, Juan Correa de Vivar pinta para el Colegio de Doncellas de Toledo una Virgen del pajarito, tema que interpretó Morales en 1546 y que se considera su primera obra ${ }^{6}$; no hay que olvidar tampoco, desde el punto de vista formal, la influencia que para esta obra de Morales tuvo la pintura de la Virgen y el Niño en la Huida a Egipto, de Fernando Llanos. Sobre la interrelación que pudo haber entre Morales y Correa en la década de los 40 y posteriores, queremos destacar las coincidencias temáticas y estilísticas entre algunas de sus obras. Ya nos hemos referido a la Virgen del Pajarito, pues bien en la Historia de San Pedro con Safira y Ananías que Correa pintó para el monasterio de San Martín de Valdeiglesias, actualmente en el Museo del Greco de Toledo, Safira lleva un sombrero decorado por lazos de gasa cruzados como los que también aparecen en las numerosas Vírgenes del Sombrero de Morales, tema al que nos referiremos más tarde. En el año 1546 Correa de Vivar se halla pintando el retablo mayor de la iglesia de San Juan en Herrera del Duque (Badajoz), obra que no se asentará hasta el 1550. Por esos años Morales, no llega a ejecutar el encargo del retablo de Puebla de la Calzada que se le había encargado, pero las conexiones entre Morales y Correa siguen siendo evidentes en el color que el extremeño emplea en sus primeros retablos y en el sentido dramático con que Correa expresa las escenas de la pasión. En ellas ambos maestros manifiestan el dolor por medio no solo del claroscuro sino de gestos afligidos subrayados por las bocas entreabiertas, las cejas curvadas y fruncidas, los ojos de mirada traspuesta, y manos que a veces se entrecruzan hasta marcar dolorosamente los nudillos. Algo distingue a Morales de Correa en estas escenas, la acentuación del patetismo por medio de un claroscuro más intenso y los tonos de color monocromos y fríos de las indumentarias. Pueden servir de ejemplo la citada Piedad de la Academia de San Fernando, y las diversas Piedades de Correa. En esta línea son también comparables El Calvario con donante de Morales, del museo Provincial de Valencia (fig. 3), y el de Correa en la iglesia del Salvador de Toledo, (fig. 4), en el que, además, el pintor toledano destaca sobre fondo oscuro las figuras del banco trayéndolas a primer plano, característica que se ha destacado en el estilo de Morales. Este amor por el fondo oscuro colocando las figuras en primer plano la hallamos también, en otro toledano, Pedro Machuca, quien en su Sagrada Familia pintada en 1520 para la catedral de Jaén (fig. 5), resalta estas características y, además, iconográficamente, puede considerarse precedente de las Vírgenes de la Leche, de Morales (fig. 6). Nada más ilustrativo para este tema que los versos del valenciano Moseen Tallante, a finales del siglo XV, quien escribe el Loor de las XX excelencias de Nuestra Señora, y entre ellas, "el nudrir del Hijo de Dios", relativas a la Virgen de la Leche que comentamos: "Humanas pasiones del nuevo nacido / notaba la santa con gran atención, / afijos los ojos en la redención, / de que sustentarle no puesto en olvido, / aquel que escudriña lo más escondido, / bastece y abundan por vías directas, / aquel trajo fuentes en las sacras tetas / de limpios licores de que fue nacido". El concepto de la entrega del alma después de la muerte con alguna presencia "divina" hace relacionar el Juicio del Alma de San Juan de Ribera de Morales con la Muerte de San Bernardo, y los dos Tránsitos de la Virgen, que Correa pintó respectivamente para el monasterio de San Martín de Valdeiglesias (Museo de Pontevedra), Nuestra Señora del Tránsito de Toledo (Museo del Prado) y tríptico del convento de las Jerónimas de San Pablo en la misma ciudad. La iconografía del Cristo Varón de Dolores, del que Morales hizo tantas versiones, hemos elegido el magnífico Ecce

\footnotetext{
6 Gaya NuÑo, loc. cit. nota 2. Cita de pasada la influencia posible de Correa de Vivar. Se ha querido ver formalmente influida por la Virgen de Pez, de Rafael en el Prado. También Rafael pintó una Virgen del Jilguero (Ufizzi de Florencia), pero curiosamente la composición de Morales recuerda la de Nicolás Francés, con el mismo tema, en el retablo de San Francisco que se conserva en el Prado, procedente de La Bañeza, en la provincia de León.
} 


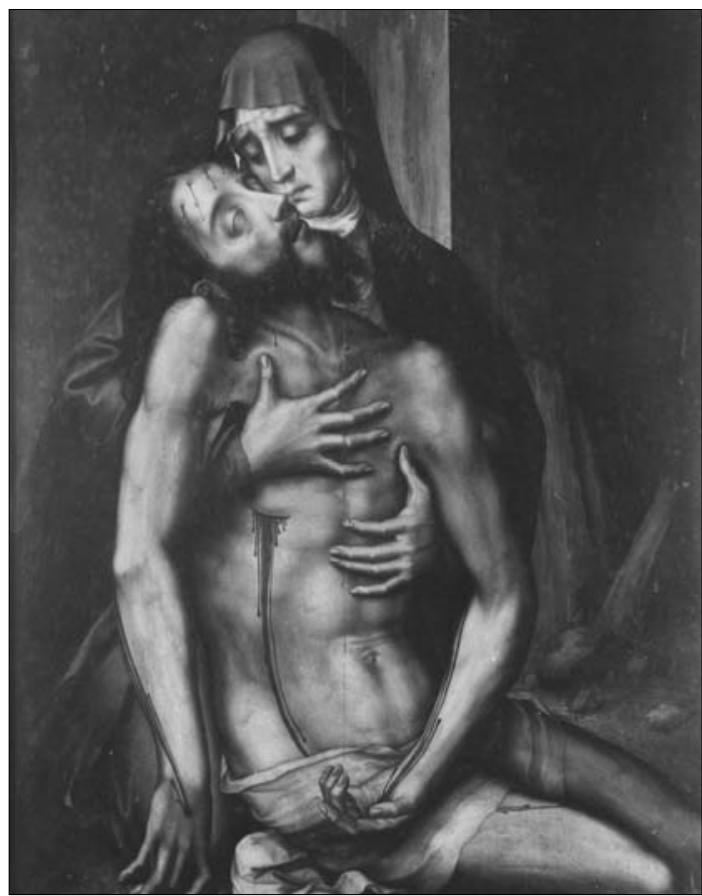

Fig. 1. L. de Morales, La Piedad. Madrid, Academia de San Fernando.

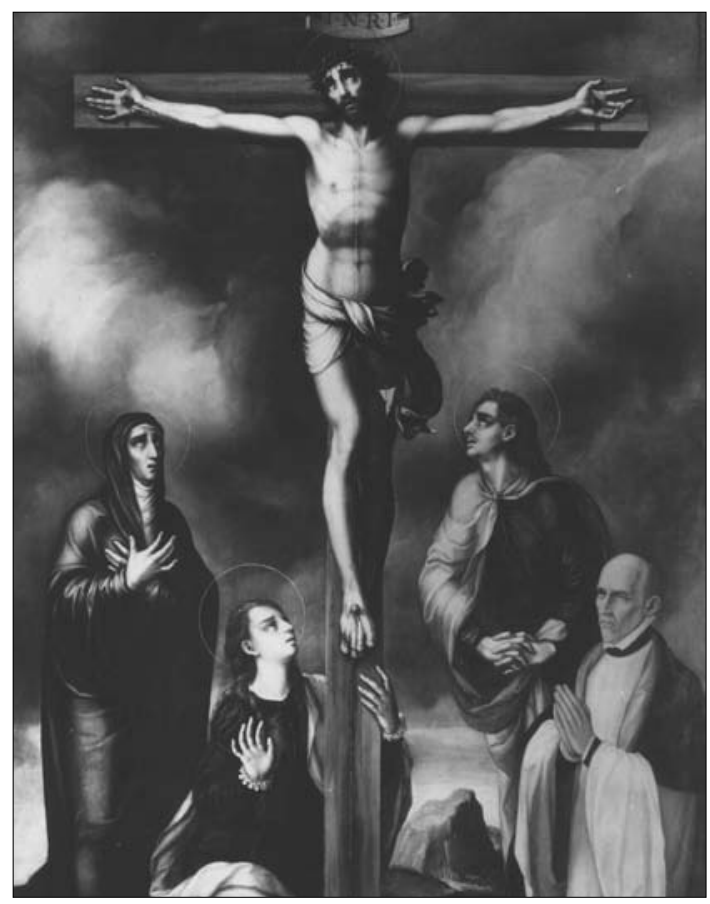

Fig. 3. L. de Morales, Calvario. Valencia, Museo Provincial.

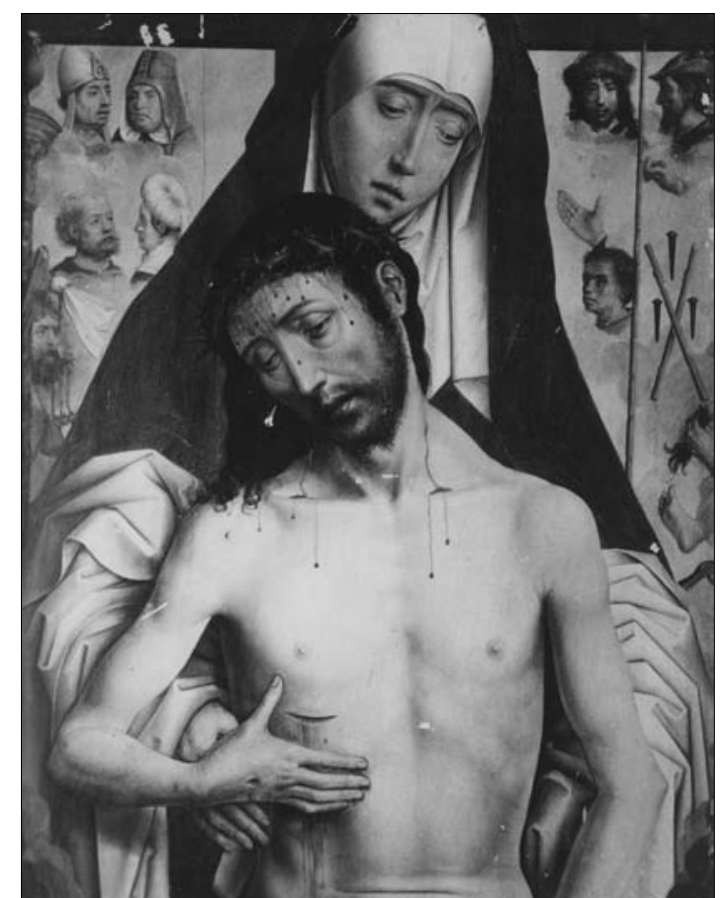

Fig. 2. Memling, La Piedad. Granada, Capilla Real.

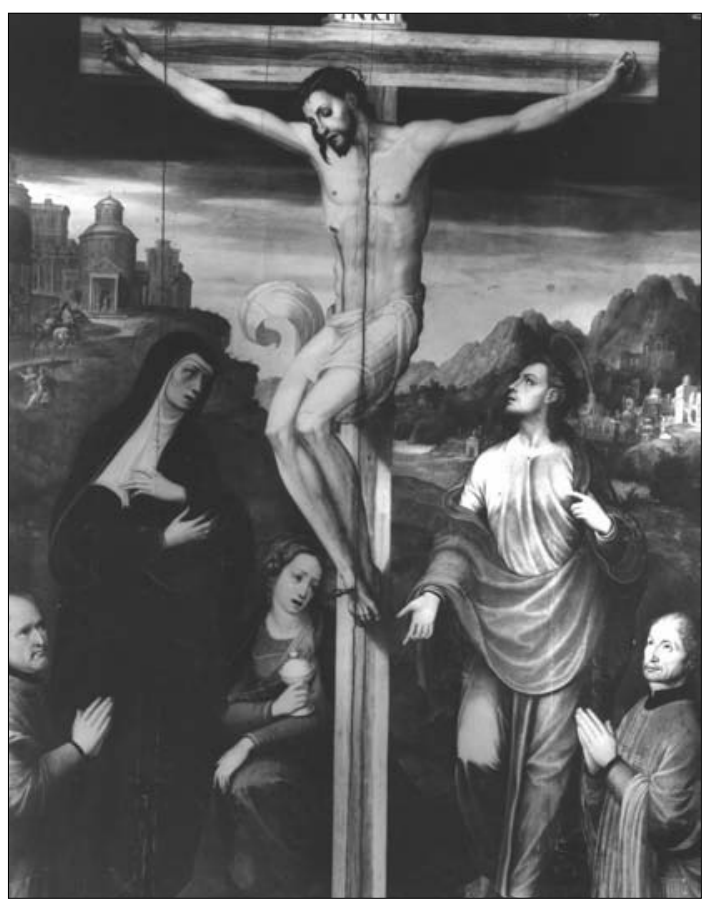

Fig. 4. J. Correa de Vivar, Calvario. Toledo, Iglesia del Salvador. 


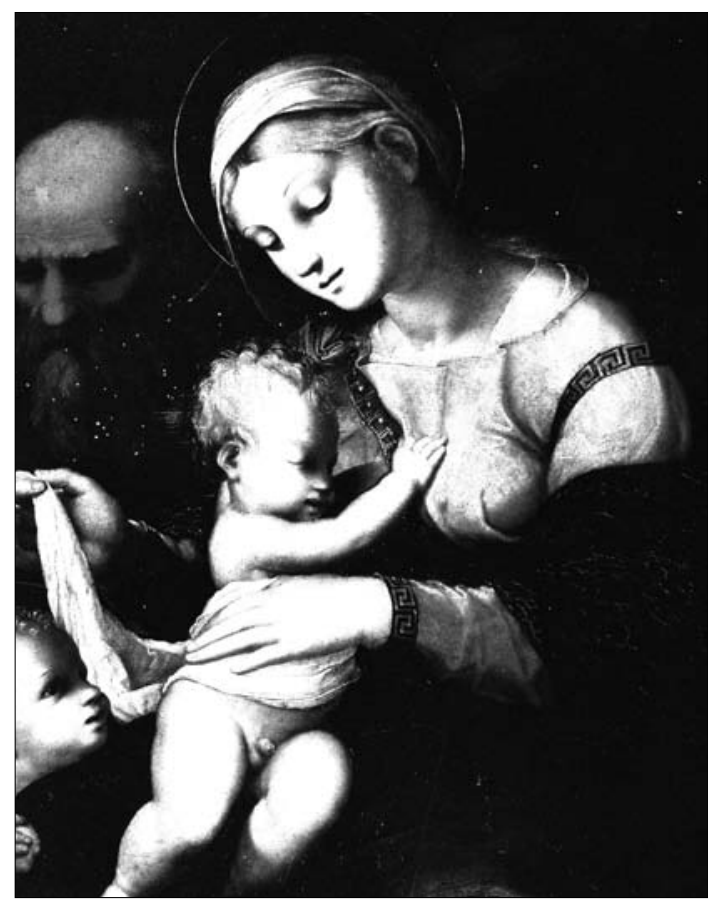

Fig. 5. P. Machuca, Virgen de la leche con San José y San Juanito, Jaén, catedral.

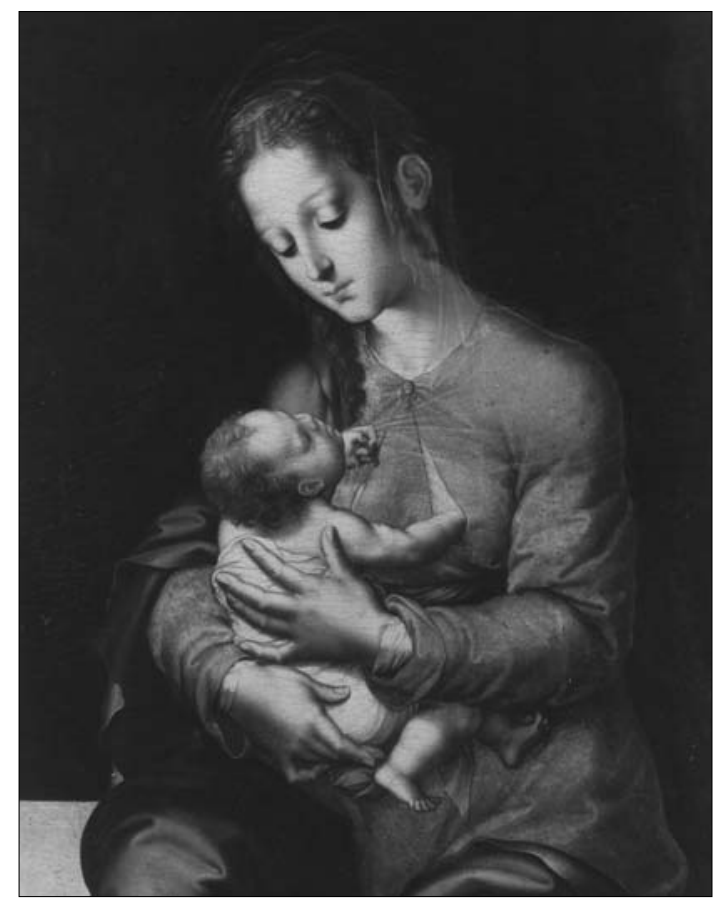

Fig. 6. L. de Morales, Virgen de la leche, Madrid, Museo del Prado.

Homo de la colección Arango (fig. 7), porque puede derivar del modelo de Jesús meditando ante la Cruz que Correa pintó para el retablo del coro de monjas, del convento de las Jerónimas de Toledo, y del Cristo con la Cruz a cuestas del retablo de Calzada de Calatrava. Todas estas obras fueron realizadas en la década de los sesenta, antes de que Correa muriera en 1566 (fig. 10-11) ${ }^{7}$. No cabe duda de que el ejemplar de Arango es uno de los más bellos del tema pintado por Morales. Su colorido monocromo en marrones rojizos hace resaltar la palidez del bello rostro suavemente modelado por un claroscuro esfumado que lo ponen en conexión con el modelo de la colección García de Madrid (fig. 8), con otro en colección desconocida (Bäcksbacka Cat. n ${ }^{\circ} 53$ ) y con el del tríptico con el retrato del beato Ribera, de propietario desconocido (ídem, Cat. ${ }^{\circ} 45$ ). La forma de colocarle la túnica en escote redondo y atada al hombro derecho la utilizó Morales en el San Juan Bautista que se conserva del pintor en el Prado (fig. 9). Modelo muy similar, pero anterior, es el de San Juan Bautista que Correa pintó para una Capilla funeraria (fig. 12). La técnica empleada por Morales en el Ecce Homo de Arango es suelta en el tratamiento del cabello y la oreja, recordándonos las observaciones que hizo Pérez Sánchez al respecto de la presencia de esta técnica en el San Jerónimo y algún profeta del retablo de Arroyo de la Luz. El momento elegido por Morales para este Ecce Homo se halla entre el Juicio y el Expolio antes de atarle la soga al cuello (Mat. 27, 28-30), es el "Hombre del Dolor", descrito por Isaías (50, 4-11: El Mesías, víctima) cuya descripción recogieron los primitivos flamencos en su vertiente de devoción íntima y particular de la Pasión de Cristo, a la que no fueron ajenas las Revelaciones de Santa Brígida y a las

7 I. Mateo GómeZ, Juan Correa de Vivar, Madrid, 1983; idem, "Nueva aportación al catálogo de Juan Correa de Vivar", Archivo Español de Arte, 1988, n² 243, p. 313; I. MATEO GómEZ y A. LóPEZ-YARTO, La pintura toledana de la segunda mitad del siglo XVI, Madrid, 2003, p. 168-213. 


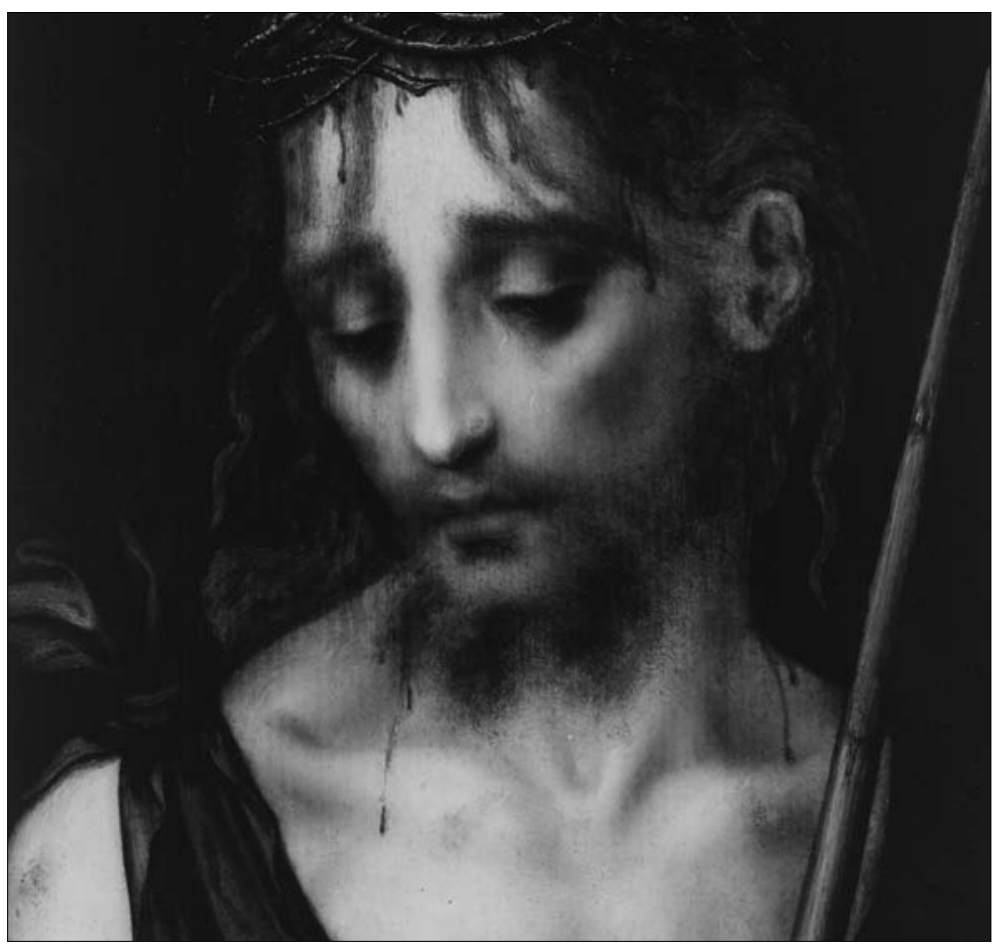

Fig. 7. L. de Morales, Ecce Homo, Madrid, colección Plácido Arango.

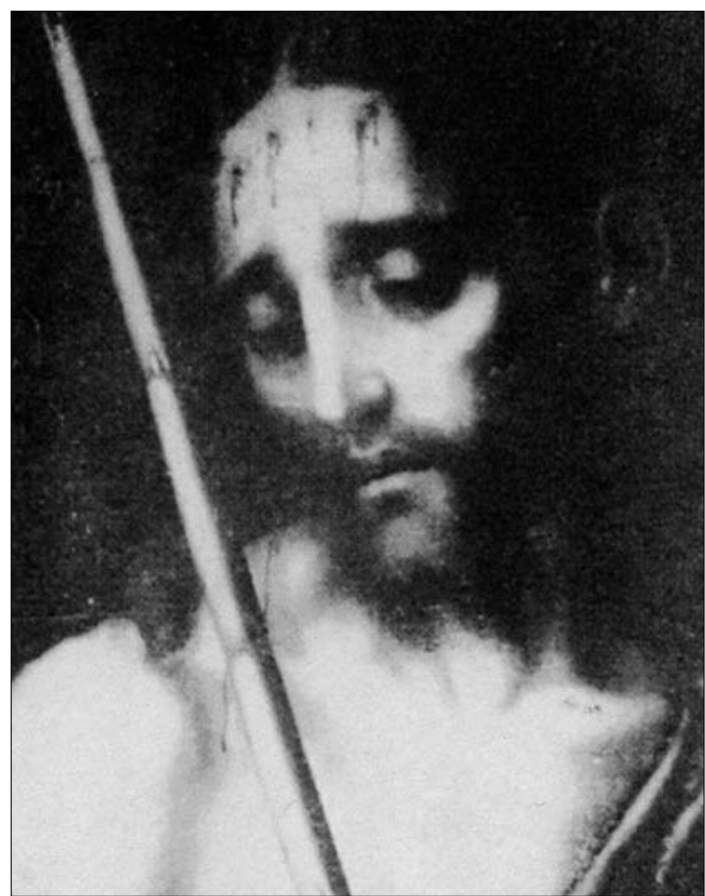

Fig. 8. L. de Morales, Ecce Homo, Madrid, Colección García.

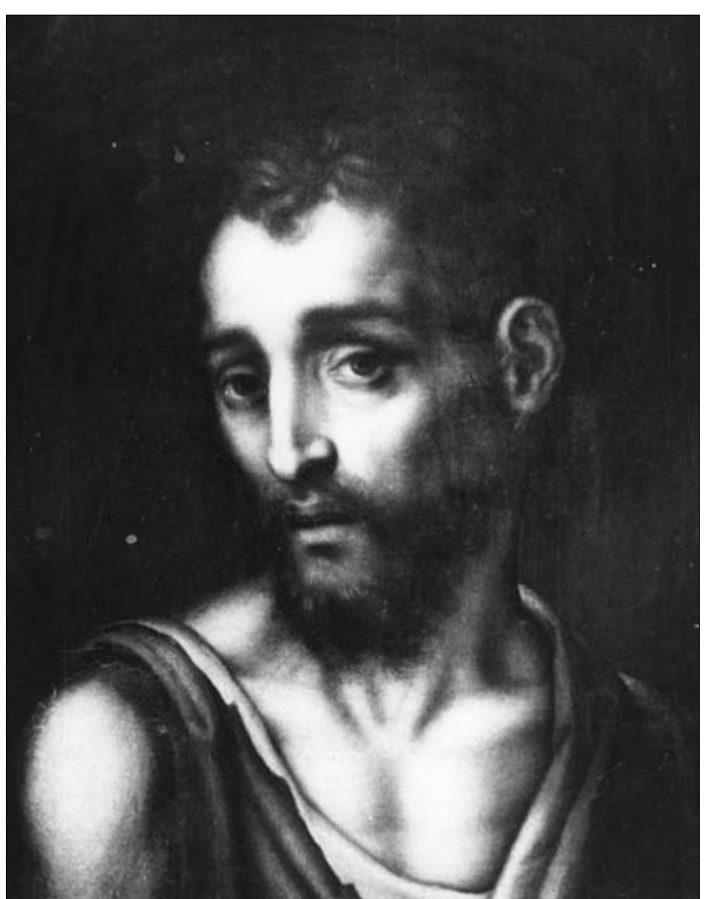

Fig. 9. L. de Morales, Juan el Bautista, Madrid, Museo del Prado. 


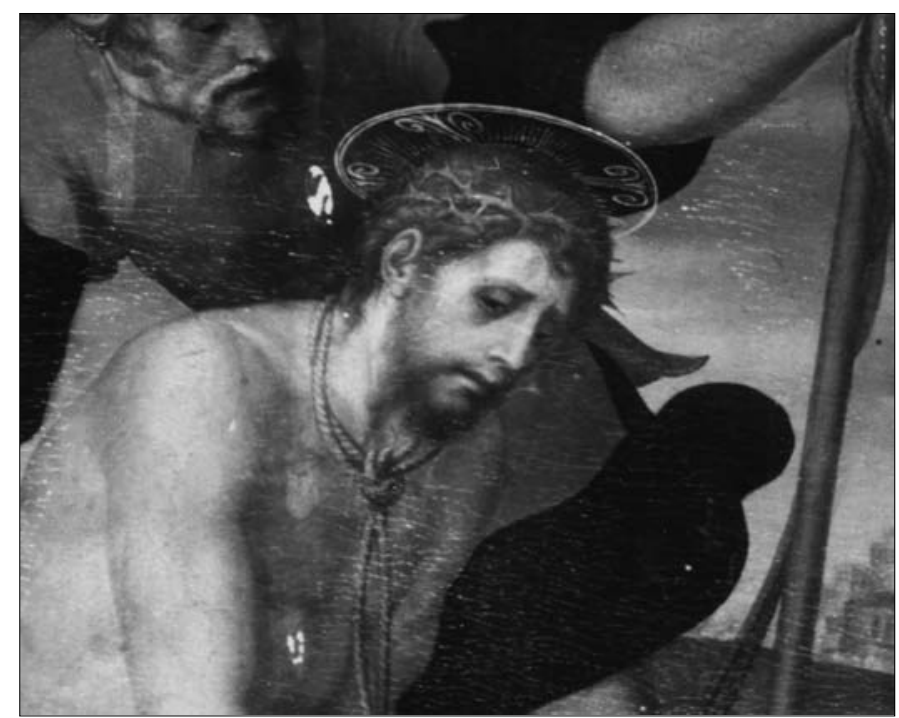

Fig. 10. J. Correa de Vivar, Cristo contemplando los elementos de la Pasión (detalle), Toledo, Convento de Jerónimas de San Pablo.

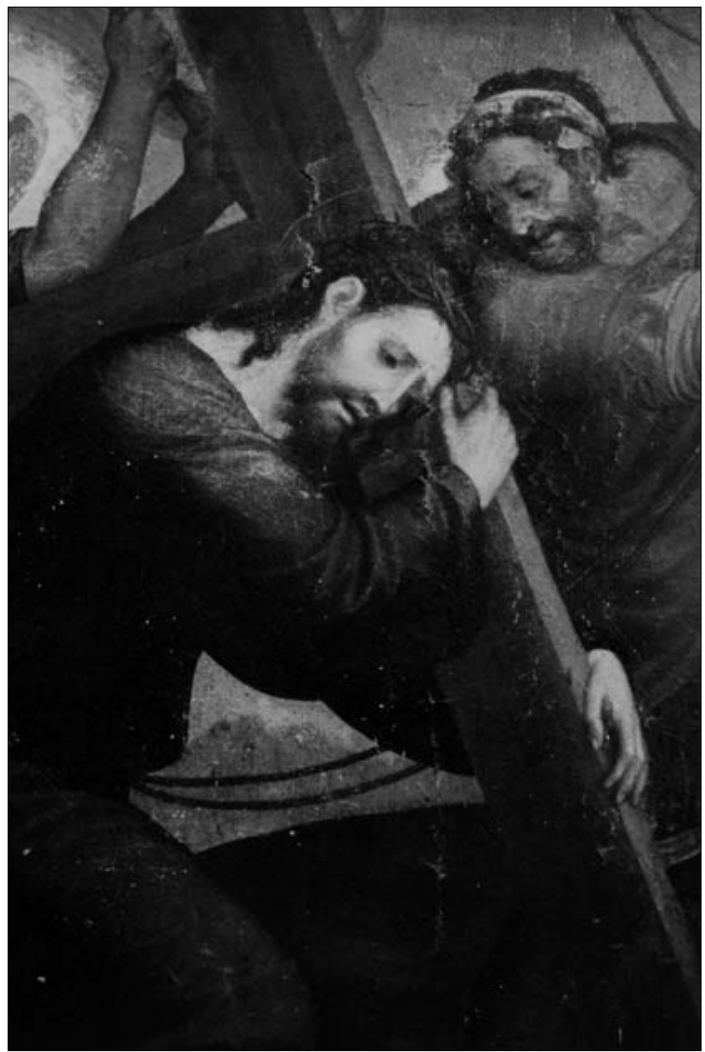

Fig. 11. J. Correa de Vivar, Cristo con la Cruz. (detalle). Calzada de Calatrava (Ciudad Real), Iglesia Parroquial.

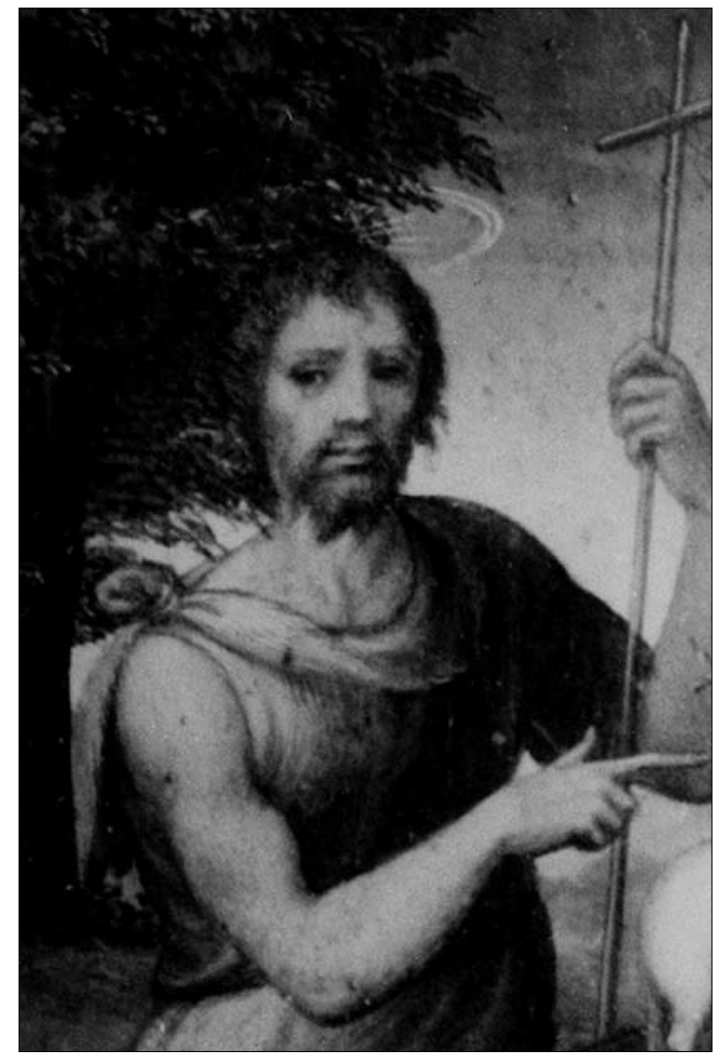

Fig. 12. J. Correa de Vivar, Juan el Bautista (detalle), paradero desconocido.

AEA, LXXX, 317, ENERO-MARZO 2007, 7-24, ISSN: 0004-0428 
que sin duda se sumó Morales, calificado en este sentido por Pérez Sánchez como un "gótico secreto".

Juan Correa de Vivar muere en 1566, Morales veinte años después. Para el extremeño fueron estos años su periodo artístico más fructífero, hasta su muerte. El pintor contó con el mecenazgo de San Juan de Ribera quien, aún después de su traslado a Valencia en 1568, siguió protegiéndole. Las características del estilo de Morales se hallan claramente definidas, pero en cuanto al color que se observa en algunos de sus retablos y tablas, no podemos obviar el espléndido retablo del flamenco Cornelio Cyaneus - establecido en Toledo - pintado en 1562 para la iglesia de Villar del Pedroso (Cáceres), en el que el esfumato y claroscuro manierista, los fondos oscuros en las escenas e incluso cierta iconografía como las "Lágrimas de San Pedro" pudieron conectar con la sensibilidad de Morales ${ }^{8}$. Para finalizar con las influencias toledanas en Morales, Rodríguez G. de Ceballos ha sugerido la influencia que pudo tener el texto del Flos Santorum, del toledano don Alonso de Villegas, en el capítulo correspondiente a la iconografía de la Presentación del Niño en el Templo, de la que Morales hizo dos versiones, la del retablo de Arroyo de la Luz y la que se conserva en el Prado9.

Respecto a influencias italianas, el Cristo con la cruz a cuestas del Piombo claramente se halla presente en Morales. Las esfumaturas de Luini, al modo de Leonardo, las debió conocer Morales en las obras que se conservaban de este pintor en España. Así, en su Sagrada Familia de Roncesvalles y en la Virgen con Jesús y San Juanito de la Catedral Nueva de Salamanca, reproduce los famosos niños de Luini abrazándose. Pero también hay que tener en cuenta la presencia de Morales en Valencia, sin duda a partir de ser trasladado San Juan de Ribera a dicha ciudad. En ella debió conocer también lo "leonardesco" a través de los "Hernandos", en los que el claroscuro y el esfumato estaban presentes. El claroscuro y el esfumato aparecían también en ejemplos manieristas, no solo en el citado toledano Machuca sino también en el vallisoletano Berruguete, del que había un ejemplo importante para Morales en Toledo: la tabla de San Juan Bautista para el convento de Santa Úrsula ${ }^{10}$.

Las bellas cabezas de la Virgen con el Niño de Morales, de cabellos dorados cayendo en tirabuzones a modo de patillas y minuciosamente dibujadas, evocan los modelos de Correa de Vivar. No hay nada más que comparar con la Virgen de la Anunciación del Prado, y las Vírgenes, de pie, con el Niño, de Correa, en convento de Jerónimas de San Pablo, y de Morales en el Museo de Arte Antica de Lisboa. Las conexiones de Morales con el mundo flamenco ya se han apuntado, pero creo que no hay que olvidar la figura de Miguel Coxcie, del que en España había abundante obra en El Escorial, cuyos esbirros en los temas de la Pasión pudieron influir en los que aparecen en los Ecce Homo que pintó Morales ${ }^{11}$.

Queremos terminar citando la influencia portuguesa en Morales. Portugal como España estuvo influida por el mundo flamenco y por el italiano, por ello, pensamos, que tal vez no se ha subrayado la importancia que pudo tener en Morales el pintor Antonio de Holanda, establecido en Portugal, y padre del famoso Francisco de Holanda. Sabemos que Antonio de Holanda había pintado en Toledo en 1529 los retratos de Carlos V y de Isabel de Portugal, cuando el pintor debía contar aproximadamente unos cuarenta y nueve años. Como Antonio de Holanda muere en 1557, su obra artística pudo conocerla Morales bien en España o en Portugal, cuando empezaba su periodo de formación. Al parecer la emperatriz, que conocía la obra de Antonio de Holanda cuado estaba al servicio de Manuel I y de Juan III de Portugal, le envió llamar antes de que Carlos V marchara a

\footnotetext{
8 I. MATEO Gómez y A. LóPEZ-YARTo, loc. cit. nota 7, p. 213-216.

9 A. Rodríguez Gutiérrez de Ceballo, "El Mundo espiritual del pintor Luis de Morales”, Goya, 1987, n 196, p. 202.

${ }^{10} \mathrm{~F}$. BentTo, loc. cit. nota 5. Apunta la influencia de Alonso Berruguete en Morales.

11 Catálogo de la Exposición Las tablas flamencas en la Ruta Jacobea, San Sebastián, 1999, p. 362-363.
} 
Italia para su coronación imperial encargándole unos retratos ${ }^{12}$. Siguiendo el texto de Redondo Cantera, Carlos V quedó satisfecho de la imagen que de él obtuvo el pintor flamenco, y así se lo transmitió a su hijo Felipe II posteriormente: "ninguén o retratara melhor que meu pai en Toledo, mem Ticiano". Esta apreciación del emperador sobre Antonio de Holanda la transmitió su hijo Francisco de Holanda en su obra Da Ciencia do Dosenho (Lisboa 1985, pp. 42-43). La relación de Antonio de Holanda con la emperatriz - a la que luego nos referiremos detenidamente en un caso concreto de la Virgen del Sombrero - propició otros servicios artísticos prestados a la emperatriz en Toledo, trabajos que le proporcionaron a Holanda mayor prestigio. Entre ellos estaría la colección de libros iluminados que poseyó la emperatriz, así como dos retablos guarnecidos de plata. También el pintor portugués tuvo otros contactos con doña Isabel, haciendo para ella una serie de retratos de los hermanos de la emperatriz, recibiendo por ello mercedes personales ${ }^{13}$.

Desde luego los contactos portugueses de Morales se evidencian, también, en cuanto al color, iconografía y aspectos formales. Es evidente la simbiosis de lo nacional y lo flamenco en el mundo pictórico manierista portugués: Gregorio Lopes, Diego de Contreiras y Mestre de Romeira, son autores a tener en cuenta para su formación. Estos pintores, que, además, evocan el estilo pictórico que había en el Toledo de aquellos años ${ }^{14}$.

Morales, pintor complejo, aúna el sentir manierista cadencioso aprendido en Toledo, no ajeno a la melancolía o "saudade" portuguesa. Quizá su grandeza consistió en conseguir un estilo propio a base de muchas enseñanzas, unas lejanas como las flamencas e italianas, y otras más próximas a Badajoz, su lugar de trabajo, como la portuguesa y toledana y, desde luego, el conocimiento en sus desplazamientos a la Corte, concretamente al Escorial, de las últimas vanguardias manierista que llegaban al monasterio. Valencia por su amistad con el arzobispo Ribera, es otro foco a considerar por su vinculación con Italia.

El supo como nadie recoger el mundo de espiritualidad íntima, al que siempre se había inclinado el cliente español, con tanto acierto ha descrito Rodríguez G. de Ceballos comparándola, con matices, con la del Greco, justificando el "exceso expresivo y reiterativo" de las representaciones religiosas de Morales, en las escenas de la Pasión, por el momento de "experiencias religiosas innovadoras vigiladas por los tribunales de la Inquisición"15. Fernando Marías recoge lo publicado por Rodríguez G. de Ceballos sobre el ambiente intelectual y religioso de la época de Morales ${ }^{16}$, destacando en sus páginas la influencia que sobre la expresión religiosa de la obra de Morales pudieron tener sus comitentes, entre los que se encontraban nobles y tres importantes prelados: Navarra (1546-1556), Cristóbal de Rojas y Sandoval (1556-1562) y Juan de Ribera (1562-1569). La preparación intelectual de los tres influiría en la obra de Morales para hacer de ella una "oración mental" de raíz erasmista o un "método imaginativo de meditación devocional", al modo de los Ejercicios de San Ignacio. Creo que en efecto en alguno de los cuadros de Morales, como los del Juicio del Alma, y El Cristo meditando ante los elementos de la Pasión, además de las evocaciones de las citadas obras de Correa de Vivar, pueden hallarse correspondencias, como sugieren estos autores, con el texto de la Agonía del tránsito de la muerte, de Alexo de Venegas y con el De la oración y consideración, de Fray Luis de Granada, que es todo un ejercicio

\footnotetext{
12 M. J. Redondo CANTERA, "Artistas y otros oficios suntuarios al servicio de la emperatriz Isabel de Portugal" en II Congreso Internacional de Historia da Arte, 2001, Portugal: Encruzilhada de Culturas, das Artes e das Sensibilidades. Actas, p. 657-662.

13 loc. cit. nota 12

14 M. T. Desterro, O Mestre Romeira e o Manierismo escalabitano, 1540-1620, Coimbra, 2000.

15 Rodríguez G. DE CEBALlos, loc. cit. nota 9.

16 F. MARÍAs, loc. cit. nota 1, p. 342-343.

17 F. MARíAs, loc. cit. nota 1, p. 344-347.
} 
de meditación sobre todo aquello que sucederá antes y durante la Pasión ${ }^{17}$. Ascéticos y místicos acompañan a Morales en su obra ${ }^{18}$, pero ésta trascendió más allá de los comitentes de la nobleza o de importantes eclesiásticos. La obra del extremeño se convirtió en algo más cercano, sencillo, piadoso e íntimo, requerida por conventos y particulares, que satisfacían su espiritualidad con las obras del pintor, y que al contemplarlas, como decía Santa Teresa, aspiraban a "un encogimiento suave en lo interior, como verá quien pase por ello" (Moradas, $4^{\text {a: }}$ Oración de Recogimiento). En resumen, el mundo espiritual propiciado por Trento explica el éxito de su escasa iconografía y la necesidad de la creación de un taller que satisfaciera a la numerosa clientela. Este taller, generalmente de calidad, repitió sin cesar la Piedad, el Ecce Homo, la Virgen con el Niño, y la Virgen del Sombrero, incluso después de la muerte de Morales.

Entre los temas que hemos citado de más éxito en la obra de Morales se halla la Virgen del Sombrero, también conocida por la Virgen Gitana. Como en el caso del Ecce Homo de Arango, en esta colección se halla una de las más bellas versiones y de mayor calidad, si no la más, de la obra del maestro. Recientemente ha sido expuesta en el Museo de Bellas Artes de Oviedo (fig. $13)^{19}$. Independientemente de la excelente técnica empleada, lo más destacable en ella es la "melodía" de tonos azulados de diversos matices que invade la composición. La Virgen parece bañada por la luz de la luna, serena, como la describió Angulo en otros ejemplos de Morales ${ }^{20}$. La escena parece tener lugar, pues, durante la noche, lo que la pondría en contacto con la iconografía que se le ha atribuido, como un pasaje de la Huida a Egipto durante la noche.

El sombrero que cubre la cabeza de la Virgen de la colección Arango está cubierto por finas cintas entrecruzadas de gasa transparente que deja ver el color rosado suave del soporte del sombrero. El borde del ala es redondeado y de un grosor superior a los ejemplares de las colecciones de Adanero y Balanzó (figs. 14 y 15), hallándose su hechura más próxima a otra versión que Solís localiza, también, en la colección Adanero y a la que nos referiremos más tarde (fig. 16). Respecto a la Virgen de la colección Adanero (fig. 14) debemos llamar la atención sobre la pequeña mosca que se posa sobre la manga del brazo izquierdo de la Virgen. Este detalle no lo volveremos a observar hasta el ejemplar de la Virgen de las fresas del Prado, también tocada con sombrero y acompañada por San Juanito, que cubre al Niño dormido con un sutil velo sobre el que hay una mosca a la altura de la frente.

\footnotetext{
18 Tanto Alexo de Venegas como Fray Luis de Granada desarrollan su obra dentro de la Ascética española. Las fechas del toledano Venegas hace presumir que su obra pudo conocerla Correa de Vivar o alguno de sus principales comitentes los cardenales Fonseca y Tavera. Su obra citada de La Agonía de la muerte fue escrita en 1537. Sus estudiosos estiman el hecho de que su obra utiliza muchos refranes aunque no se trata de una obra filosófica escrita con ocasión de la muerte de su protector el Conde de Mélito. Respecto a Fray Luis de Granada, ocurre otro tanto respecto al conocimiento de su obra en Toledo. Curiosamente estuvo en Evora y le ofrecieron el arzobispado de Braga, que rehusó, pero fue nombrado Provincial de la Orden dominica en Portugal, y de su fama de orador tuvo constancia Felipe II cuando le escuchó predicar en Lisboa. Para subrayar estas interrelaciones hispanoportuguesas y el quehacer y admiración que unos personajes mantenían con otros y hacia otros, basta recordar que cuando muere Fray Luis de Granada, entre los que le dedican fervientes elogios se halla el protector de Morales, Juan de Ribera. Creo que no debemos olvidar en este repertorio ascético literario a Fray Alonso de Cabreros (1549?-1598), quien en la línea de Fray Luis de Granada escribió las Consideraciones sobre todos los Evangelios de la Cuaresma, dirigidas al fiel de una forma sencilla y familiar. En el ambiente se hallaban también los místicos como Santo Tomás de Villanueva (1488-1555), fray Francisco de Osuna, y Santa Teresa de Jesús - a quien don alonso de Villegas le dedica la oración fúnebre en la catedral de Toledo. La Santa de Ávila en sus Moradas habla constantemente del "alma", juicio de Dios, y en sus poesías de los dolores de la Virgen y de cómo ésta, gran amadora de su Hijo no escatima "verse tan bella” (Poesías XXIII: ¡Oh gran amadora!, en Teresa de Jesús, Castillo interior o las Moradas. Exclamaciones del alma a Dios. Poesías. Madrid, Aguilar, 1952).

${ }^{19}$ Catálogo de la Exposición, Una mirada singular. Oviedo, Museo de Bellas Artes de Asturias, 2006, pp. 8-11.

${ }^{20}$ Loc. cit. nota 1, p. 338-339.
} 


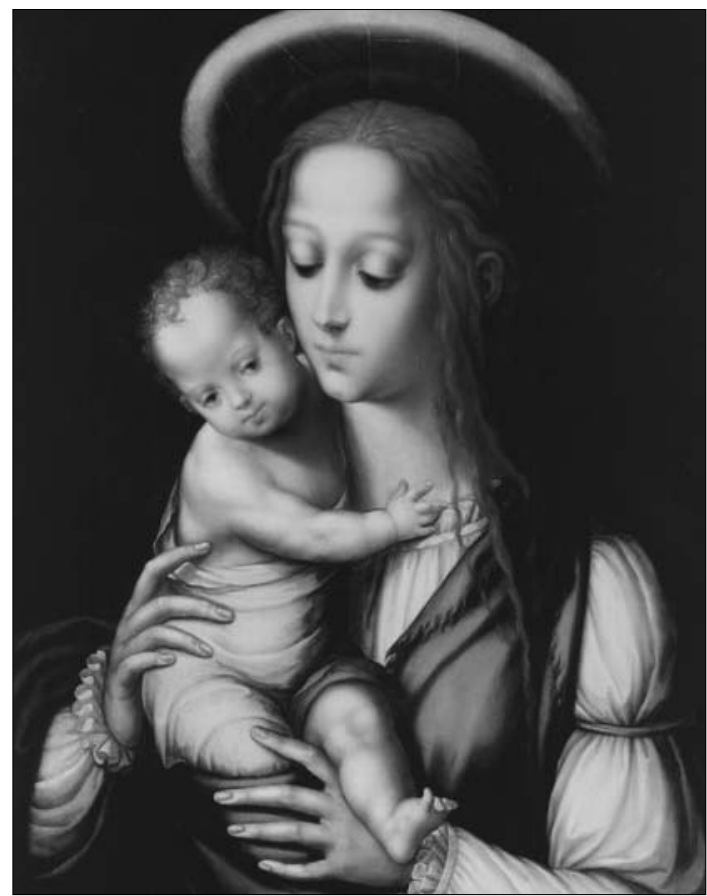

Fig. 13. L. de Morales, Virgen del Sombrerero, Madrid, colección Plácido Arango.

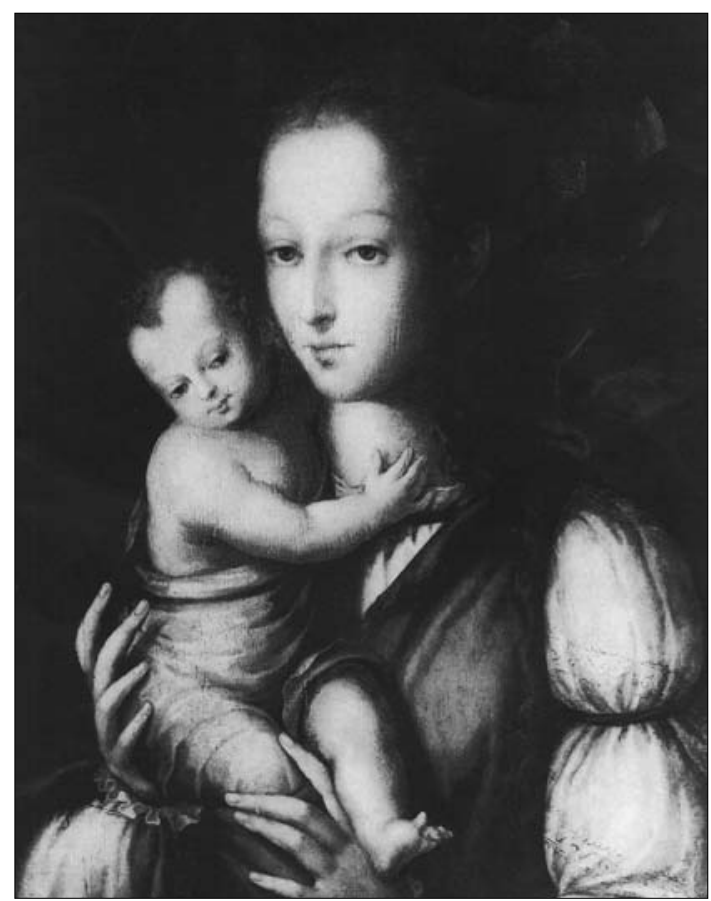

Fig. 15. L. de Morales, Virgen del Sombrerero, Barcelona, colección Balanzó.

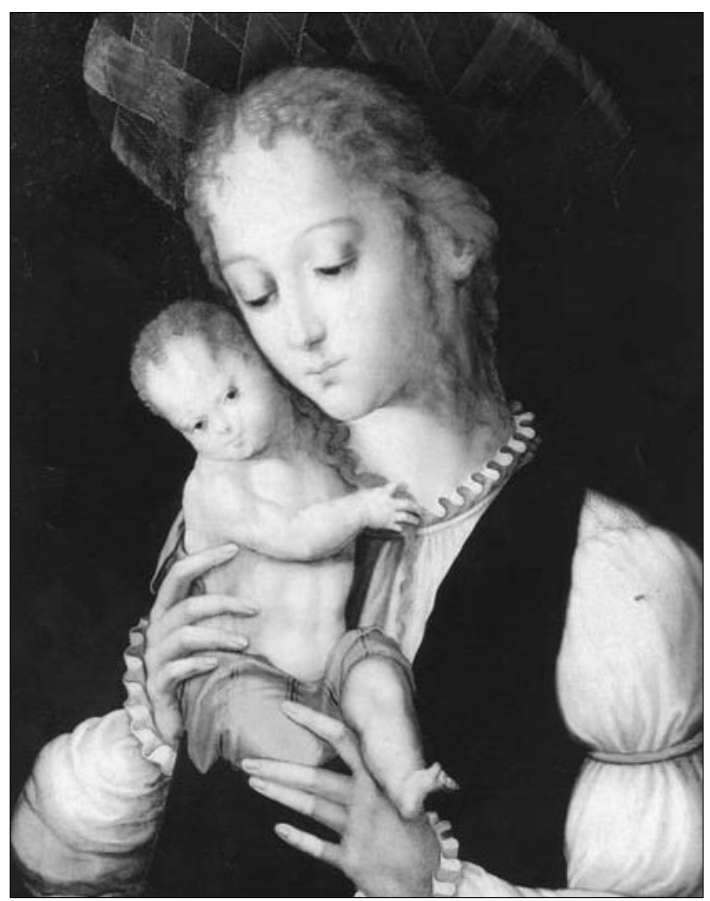

Fig. 14. L. de Morales, Virgen del Sombrerero, Madrid, antigua colección Adanero.

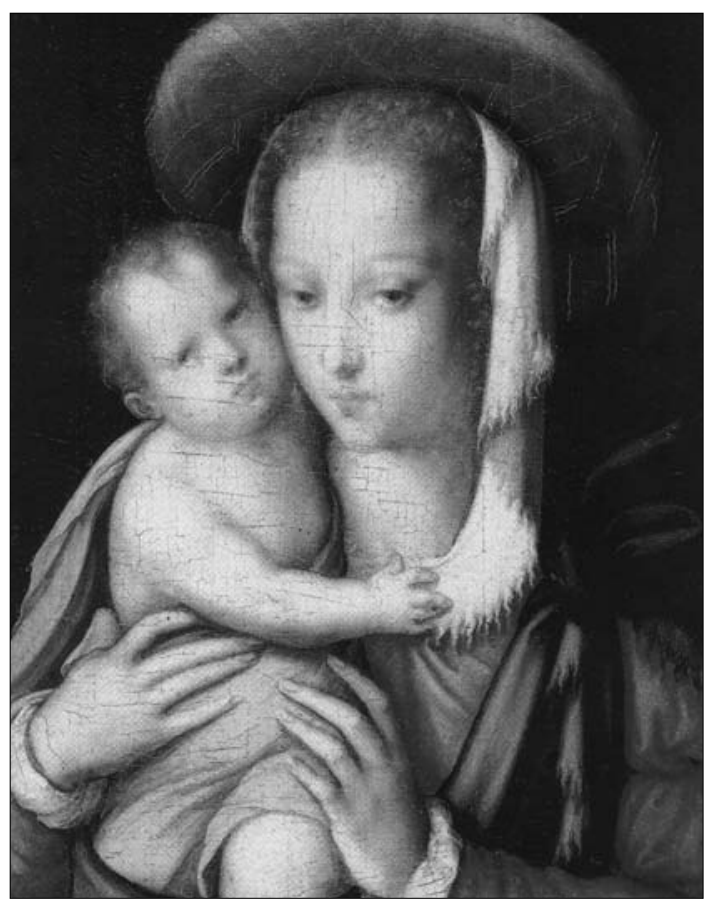

Fig. 16. L. de Morales, Virgen del Sombrerero, Madrid, antigua colección Adanero. 
Si comparamos la Virgen de Arango con las otras citadas observamos que el contraste de colores en las indumentarias de éstas últimas, las alejan de la íntima piedad emanada de la imagen más monócroma de la Virgen de Arango. Otro detalle a considerar en todas estas Vírgenes gitanas es la forma en que María lleva al Niño introducido y sujetado dentro del manto. Todo este recreo de Morales, en cuanto a la indumentaria exótica de sus Vírgenes gitanas, no cabe duda que responde, como se ha dicho, a la circulación de ciertas imágenes grabadas ${ }^{21}$, pero también debemos tener en cuenta el ambiente literario y espiritual de la época ${ }^{22}$, al que no fueron ajenos los pensamientos de Santa Teresa quien textualmente dice que la Virgen "como gran amadora de su Hijo, no escatima verse bella, y así es como se ve en estas imágenes de Morales ${ }^{23}$.

El atuendo de la Virgen ha dado lugar a varias interpretaciones. Angulo la considera como un posible precedente del tema barroco de la "Divina Pastora"; Camón Aznar simplemente considera al "sombrero" como un elemento cortesano y, Marías, como un detalle arqueológico y erudito 24.

En el año 1966 un artículo de François de Vaux de Foletier sobre la Iconographie du "Egyptiens" precision sur le costume ancien des tsiganes ${ }^{25}$, reproducía una serie de ilustraciones en las que los personajes femeninos llevaban grandes sombreros de cintas entrecruzadas y vestidas con trajes decorados por franjas respondiendo todo ello a una moda que se impuso entre los pintores europeos desde comienzos del siglo XVI al XVII, alcanzando tanto a personajes profanos como religiosos. Pérez Sánchez relacionó un grabado de Desprez, que aparecía en el artículo de Vaux de Foletier, con el título de "L'Egyptienne", con un documento en el que Morales se obligaba con el obispo de Badajoz, don Juan de Ribera, para hacerle unas pinturas y entre ellas, "dos tablas de nra. Señora vestida de gitana con el niño en cada una..."26. El grabado de Desprez mostraba a una mujer con un niño, tocada por un gran sombrero decorado por cintas entrecruzadas, como los que aparecen en la Vírgenes de Morales. El grabado estaba fechado por los mismos años que el documento de Morales, 1567, comentando Pérez Sánchez que en el siglo XVI era utilizada en España la denominación de "Virgen vestida de Gitana" para ciertas imágenes, aunque la denominación se perdió.

La imagen del grabado de Desprez la hemos localizado literalmente - sin el niño - en una figura femenina de una tabla de Vicente Conducho - recientemente adquirida por el museo de Budapest - representando la Purificación de la Virgen, y que ha sido reproducida en el Catálogo de la Exposición citada en Oviedo ${ }^{27}$.

21 A. E. PÉREZ SÁnchez, “Un curioso documento sobre Morales”, Archivo Español de Arte, 1977, p. 313-316.

22 Loc. cit. nota 9, p. 194-203.

23 TERESA DE Jesús, “Poesías, XXIII: ¡Oh gran amadora!”, en Castillo interior o los moradas. Exclamaciones del alma a Dios, Madrid, Aguilar, 1952. También las hay referidas a los "dolores de la Virgen" de los que Morales, también, interpretó hermosos ejemplos.

24 ANGULO, loc. cit. nota 1, es quien sugiere la evolución del tipo hacia la Divina Pastora; CAMÓn AzNAR, "La pintura española del siglo XVI", Summa Artis, vol. XXIV, 1970, p. 470, se está refiriendo al ejemplar de la colección Adanero. A éste también se refiere GAYA NuÑo, Luis de Morales, Madrid, 1961, considerandola obra juvenil, respondiendo a un gusto popular; I. BÄCKSBACKA, Luis de Morales, Helsinki, 1962, (cat. No 76), la considera de la última época. Por nuestra parte queremos señalar que sobre la manga izquierda de la camisa de la Virgen se halla pintada una mosca; F. MARíAs, El largo siglo XVI, Madrid, 1989, p. 342.

${ }^{25}$ Gazette des Beaux Arts, 1966, $2^{\circ}$ vol., p. 165-171. Curiosamente la mayoría de los ejemplos tempranos son flamencos o alemanes, los más tardíos italianos y franceses. Efectivamente Van Lint, el pintor flamenco del s. XVII, coloca un sombrero de cintas sobre la cabeza de la hija del faraón en el cuadro Moisés salvado de las aguas, en colección privada de Málaga (ver M. Díaz PADRón, "Nuevas pinturas de Satélites de Rubens inéditas o mal atribuidas...", Archivo Español de Arte, 1988, p. 1-11, fig. 1). Pérez SÁNCHEZ publicó un cuadro de Eugenio Caxés del Museo de Bellas Artes de Oviedo, en el que la Virgen de un Nacimiento aparecía tocada con un sombrero idéntico, "Une vision nouvella de la pinture espagnole du Siècle d'or", Revue de l'Art, 1985, nº 70, p. 58-59, fig. 13.

26 Pérez Sánchez, loc. cit. nota 21.

27 Pérez Sánchez, loc. cit. nota 21, comunica que el obispo Ribera envió una tabla de la Virgen a Sevilla en 1565 y en 1566 otra al Rmo. de Ávila, también se cita una versión en la colección del Conde de Monteagudo. Tres Condes de 
El sombrero con cintas de seda entrecruzadas según se puede deducir del artículo de Vaux de Foletier, fue más usual en las pinturas del norte de Europa que en el resto. Por ello quisiéramos traer un ejemplo de los Países Bajos localizado en el Carro del Heno del Bosco, en el Prado (fig. 17). En efecto, en la parte baja de la tabla central se hallan dos mujeres tocadas con grandes sombreros de cintas entrecruzadas. Una de ellas, además, lleva a un niño recogido en el manto, del mismo modo que las Vírgenes de Morales. Por el grupo que forman junto un buhonero ciego con su lazarillo y un sacamuelas, tal vez podríamos identificarlas como "gitanas".

En la pintura portuguesa de los siglos XV y XVI - muy influida por Flandes como la castellana - hemos hallado la representación de una joven tocada con el mismo sombrero de las Vírgenes de Morales en un tabla del Maestro de Abrantes representando el Abrazo en la Puerta Dora$d a$ (fig. 18). La tabla está fechada en la década de 1540 y procede del Monasterio de Santa Clara de Santarein ${ }^{28}$. El ala delgada del sombrero de la figura del Maestro de Abrantes se engrosa en otro ejemplo portugués documentado en 1578. Se trata de la pintura al fresco llevada a cabo por el pintor de origen flamenco Francisco de Campos (fig. 19) para la bóveda de la Sala de la toma de la Goleta, en el Palacio de los Condes de Besto en Évora ${ }^{29}$.

Curiosamente el mismo sombrero de cintas con ala estrecha aparece también en la década de 1540 en Toledo, en una obra de Juan Correa de Vivar. Se trata de la historia de San Pedro con Safira (Hechos, 5), quien aparece elegantemente vestida y tocada con el sombrero de cintas entrecruzadas, cuyas bandas de seda le caen por la espalda (fig. 20). La tabla fue pintada para el monasterio de San Martín de Valdeiglesias hallándose actualmente en el Museo de la Casa del Greco ${ }^{30}$.

Correa de Vivar debió ver el modelo en Toledo y, desde luego, anterior a las versiones de Morales. En el citado documento publicado por Pérez Sánchez sobre el encargo que el obispo Ribera hace a Morales de "Vírgenes gitanas", se advierte una familiaridad con este modelo con sombrero que hace presumir - como ha señalado también Pérez Sánchez - que la representación de la Virgen vestida de esta forma era conocida. Ante ello nos preguntamos, ¿cuál pudo ser el modelo inspirador de Correa y de Morales, sobre todo en Correa, en época tan temprana? Consideramos que hay que prestar atención a la figura del pintor Antonio de Holanda, establecido en Portugal y muy considerado por Carlos $\mathrm{V}$ y la emperatriz Isabel de Portugal. Ésta última, viviendo en el Alcázar de Toledo, le encargó al pintor varios cuadros y, entre ellos, un retrato "a lo divino" de ella con su hijo, el heredero, de menos de dos años, a modo de una "Madonna". Los

Monteagudo aparecen relacionados con Toledo. El primero, Juan Hurtado de Mendoza, llamado el "Santo", fue el tercer Conde de Monteagudo y caballero de Santiago, casó con doña Luisa Chacón y Fajardo, hija del Señor de Casarrubios del Monte y de doña Francisca de Guevara, al que Carlos V nombró embajador en el Concilio de Trento. A su hijo Francisco Hurtado de Mendoza, cuarto Conde de Monteagudo, Felipe II le concedió el primer marquesado de Almazán. Estuvo casado con doña Ana de Cárdenas y Tovar, hija de Bernardino de Cárdenas, segundo duque de Maqueda y de Isabel de Velasco. Cualquiera de ellos pudo ver el retrato de Isabel de Portugal "a lo divino", de Antonio de Holanda y encargar la copia a Morales de la Virgen gitana. Todavía queda un Cárdenas, quinto conde de Monteagudo y segundo de Almazán. Casado con doña Ana Portocarrero (GARcía CARrafa, Enciclopedia Heráldica Genealógica, vol 56). Todos estos apellidos aparecen en el Toledo de la época, algunos como comitentes de obras pictóricos. (Ver La pintura toledana de la segunda mitad del siglo XVI, por I. MATEO GÓMEZ y A. LÓPEZ-YARTO, Madrid, 2003).

28 El mismo sombrero de El Bosco aparece a mediados del siglo XVI en una "Egyptienne" de una tabla de la Predicación del Bautista en el Museo de Bellas Artes de Lille (F. D. VAuX DE Foletier, loc. cit. nota 5, fig. 5); Para el ejemplo portugués M. T. Desterro, O Mestre Romeira e o Manierismo escalabitano, 1540-1620, Coimbra, 2000.

${ }^{29}$ Agradezco a María Teresa Desterro la cesión de este material fotográfico. Sobre Francisco de Campos ver a esta autora en loc. cit. nota 29, p. 96-98. La figura representada es una mujer con los pechos descubiertos y con un perrillo en el regazo. La escena nos ha traído a la memoria la cita de la Celestina de "Minerva y el can" (V. A. ÁviLA, Imágenes y símbolos en la arquitectura pintada española (1470-1560), Barcelona, 1993); I. MATEO GóMEZ y J. MATEO ViÑES, "La Celestina como fuente mitológica para el retablo de San Pelayo de Becerril: Comitente y autor", Archivo Español de Arte, 1999, p. 47-61.

30 I. MAteo GómEZ, Juan Correa de Vivar, Madrid, 1983, p. 61, lám. XXVI. 


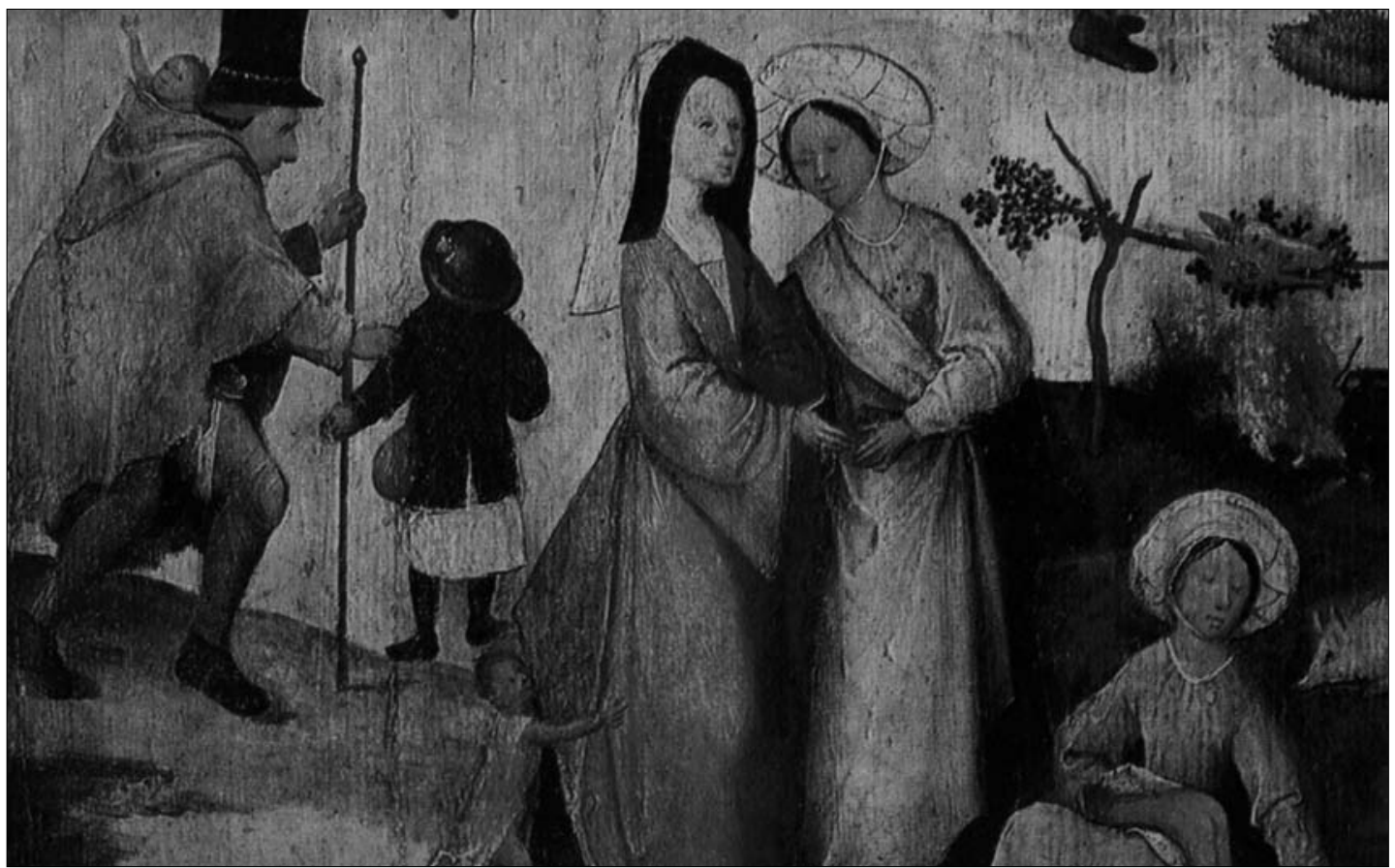

Fig. 17. El Bosco, El Carro del Heno (detalle), Madrid, Museo del Prado.

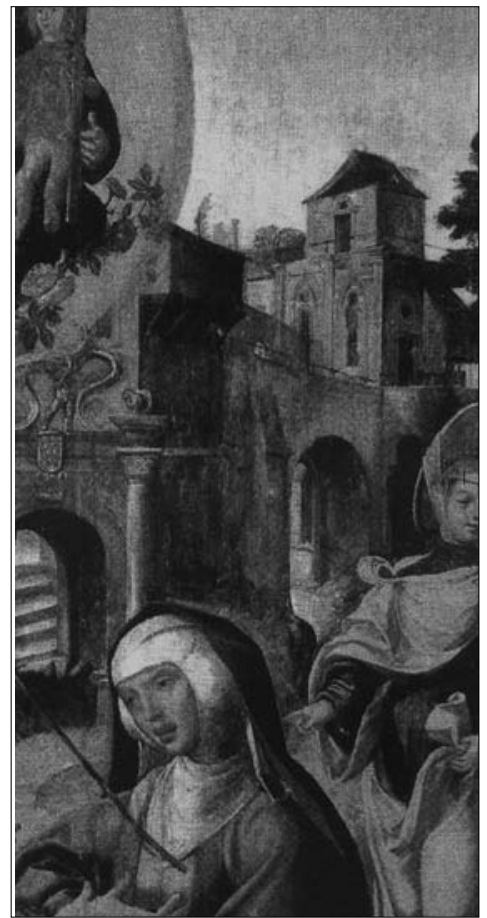

Fig. 18. Maestro de Abrantes, Abrazo en la Puerta Dorada (detalle), Monasterio de Santa Clara de Santerein (Portugal)

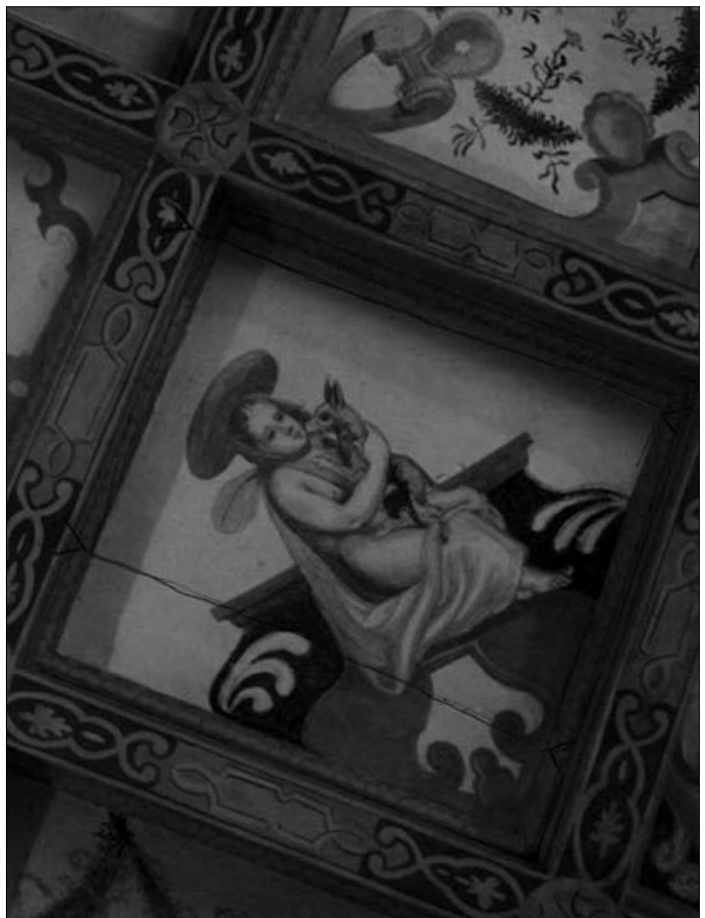

Fig. 19. Francisco de Campos, Minerva y el Can, Evora (Portugal), Palacio de los Condes de Besto. 
retratos, al parecer, se debieron llevar a cabo hacia el año 1529, antes de que Carlos V saliera de Toledo para recibir la corona imperial ${ }^{31}$.

Teniendo en cuenta la interrelación entre España y Portugal no nos debe extrañar la presencia de Antonio de Holanda en la corte española y la posible influencia que pudo ejercer en la escuela toledana, concretamente en Correa de Vivar, pues, aunque de la obra de Antonio de Holanda se sabe poco, de las miniaturas que se conservan y se le atribuyen hemos podido tener acceso a las del Libro de Horas de D. Manuel I, en las que las abundantes grisallas de los márgenes y la composición de algunas escenas nos evocan otras del pintor toledano muy principalmente en el Breviario de Carlos V, que tal vez en un principio fue encargado a Antonio de Holanda y del que después se hizo cargo Correa de Vivar. Si la influencia del portugués llegó a Toledo, también pudo influir en Morales, coincidiendo, además, ambos pintores en su trayectoria artística a un lado y otro "de la raya": en Portugal y en España ${ }^{32}$. Nos ha llevado, también, a estas conclusiones, la presencia en la Sala Christie's de Londres, de una Virgen del Sombrero con el Niño, sin duda de Morales, cuyos rasgos se pueden identificar con los de la emperatriz Isabel (fig. 21) por lo que tal vez no sería arriesgado pensar que se trata de una copia hecha por Morales del retrato que Antonio de Holanda hizo "a lo divino" de la emperatriz en Toledo, careciendo la copia de la técnica espontánea y fresca del original ${ }^{33}$. La Virgen dirige la mirada al frente - como en los retratos de la emperatriz - y el Niño, aparece con la cabeza coronada por un nimbo cruciforme dorado, apenas perceptible, que no aparece en ninguna otra versión de la Virgen del Sombrero. También hay que llamar la atención sobre su rostro, revistiendo caracteres especialmente personales, que no se repiten en las demás versiones ${ }^{34}$. Respecto a la indumentaria de la Virgen, repetida en todas las versiones, las ahuecadas mangas fruncidas de trecho en trecho por cintas, responde a la moda femenina que va desde 1526 a 1530, fecha que coincidiría con el retrato de Antonio de Holanda ${ }^{35}$. En España no era muy frecuente el retrato "a lo divino" por esos años, sí en Flandes y en Portugal, no hay nada más que recordar de éste último país el de la hermana del Emperador, doña Catalina de Portugal, pintado por Carvalho, que se encuentra en el Prado ${ }^{36}$.

De la Virgen del Sombrero de Morales existen muchas versiones casi todas reproducidas en los libros de Bäcksbacka y Solís ${ }^{37}$. Sin embargo, una de ellas siempre citada, la del convento de clarisas de Alba de Tormes (fig. 22), no ha sido reproducida, sin duda, por la escasa calidad de la fotografía debido en parte a la dureza de trazo que presenta la pintura pero, que a pesar de ello,

31 M. J. Redondo CANTERA, "Artistas y otros oficios suntuarios al servicio de la emperatriz Isabel de Portugal” en II Congreso Internacional de Historia del Arte, 2001, Portugal: Encruzilhada de Culturas das Artes e das Sensibilidades. Actas, p. 659-661.

32 Agradecemos a la profesora $\mathrm{M}^{\mathrm{a}}$ Teresa Desterro ( loc. cit. nota 14, p. 29-30) su amabilidad al enviarme las imágenes del libro de D. Manuel I. Utilizamos la frase de la Exposición Luis de Morales. A un lado y otro de la raya, Badajoz, 2000-2001.

33 Christie's de Londres, Important Old Master Pictures, Friday, 8 July 2005, n ${ }^{\circ} 17$. La radiografía del rostro no deja dudas para atribuírselo a Morales; el dibujo firme y sin arrepentimientos confirma la suposición de la copia. No hay más que compararla con la radiografía de la Virgen de la Leche, publicada el Catálogo de la Exposición: En torno a Velásquez. Pintura española del siglo de Oro, Oviedo, Museo de Bellas Artes (20 de mayo 1999-30 de enero 2000, p. 44, fig. 4).

34 Tal vez deberíamos pensar en un retrato de Felipe II a la edad en que lo pintó Francisco de Holanda.

35 C. Bernis, La indumentaria española en tiempos de Carlos V, Madrid, 1962, lám. 12, fig. 61.

36 Desconocemos donde pudo ir a parar el original del retrato "a lo divino" de la emperatriz con su hijo desde el Alcázar de Toledo. Tal vez cuando $\mathrm{M}^{\mathrm{a}}$ José CANTERA REDONDO, (loc. cit. nota 32), publique su trabajo sobre el "ajuar artístico de la emperatriz Isabel de Portugal" podemos encontrar algún dato más concreto. Ver catálogo Exposición Carlos V y su ambiente, Toledo, 1958, p. 69, $\mathrm{n}^{\circ}$ 20. En la pintura española cabría destacar el retrato a lo "divino" de Carlos V, como San Sebastián (V. Catálogo Galería Caylus de Madrid 1997-98, p. 40-43) de ámbito toledano de Juan de Borgoña, próximo a Juan Correa de Vivar.

${ }^{37}$ Loc. cit. nota 1 y 5. 


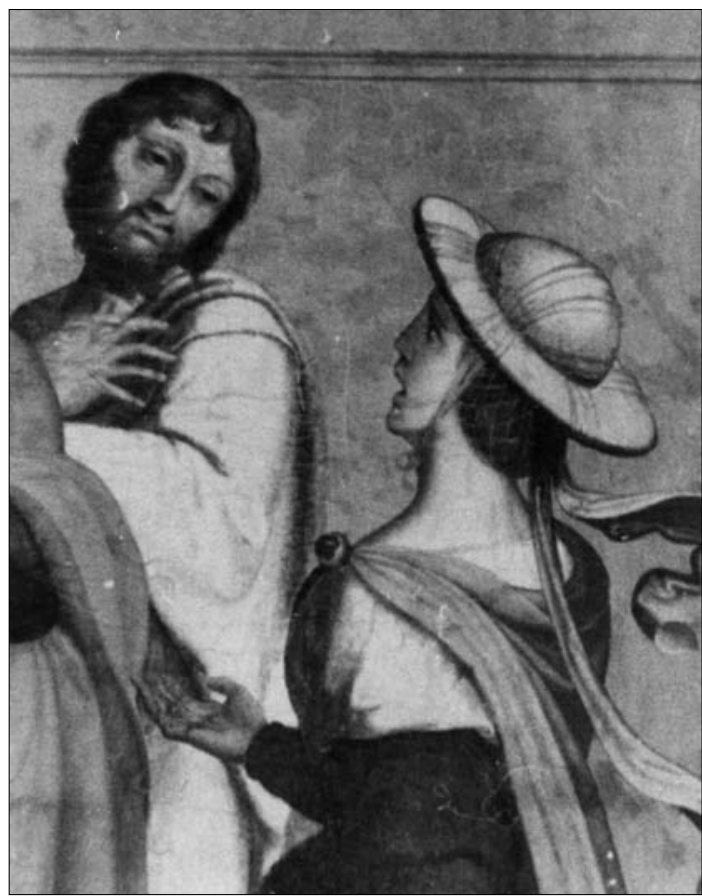

Fig. 20. J. Correa de Vivar, San Pedro y Safira (detalle), Toledo Museo de la Casa de El Greco.

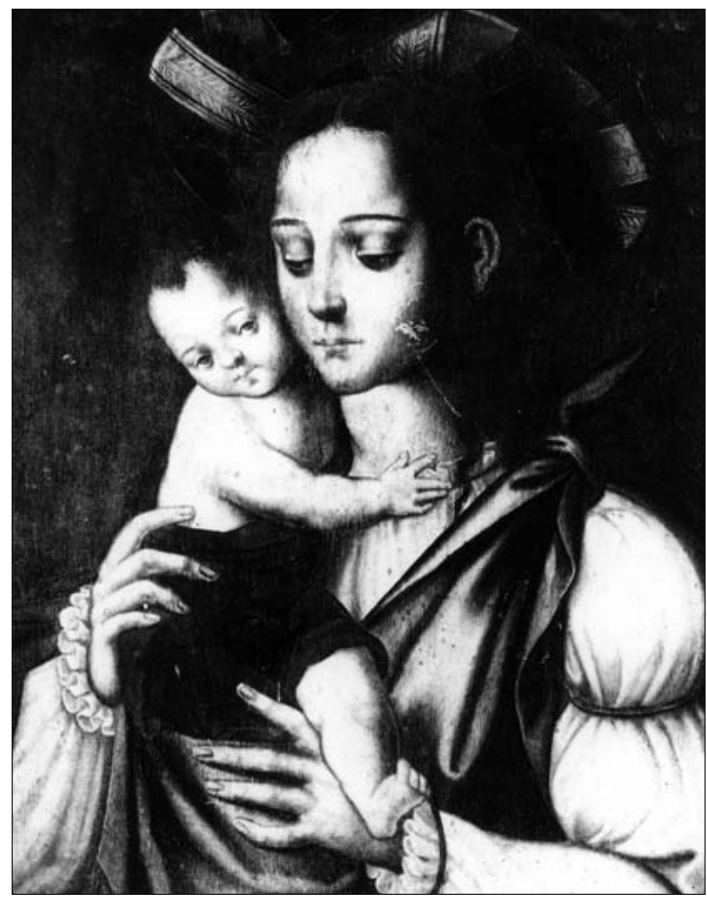

Fig. 22. L. de Morales, Virgen del Sombrerero, Alba de Tormes (Salamanca), Convento de Clarisas.

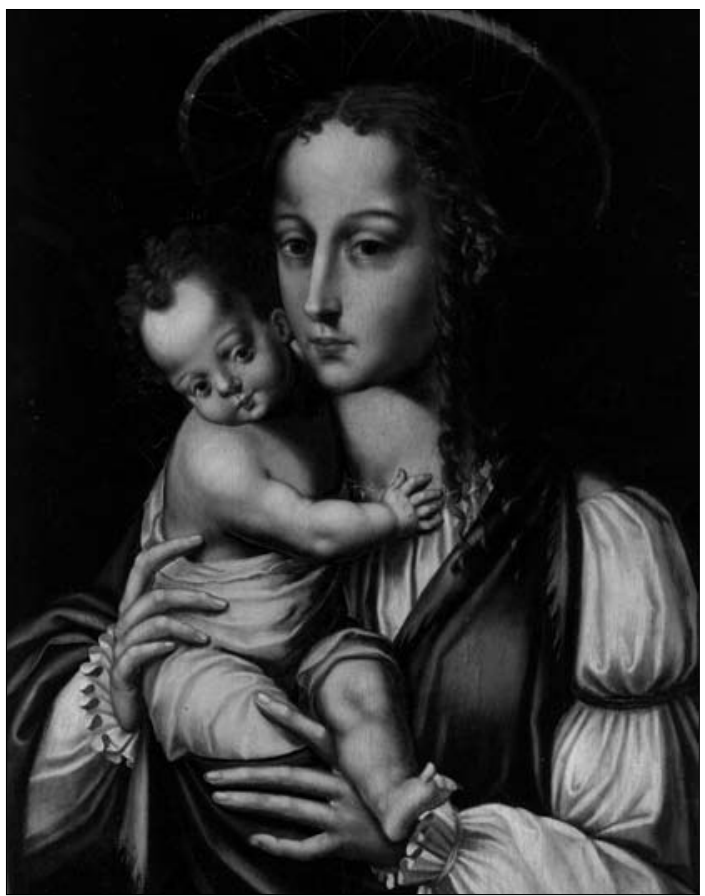

Fig. 21. L. de Morales, La Virgen del Sombrero, Madrid, colección privada.

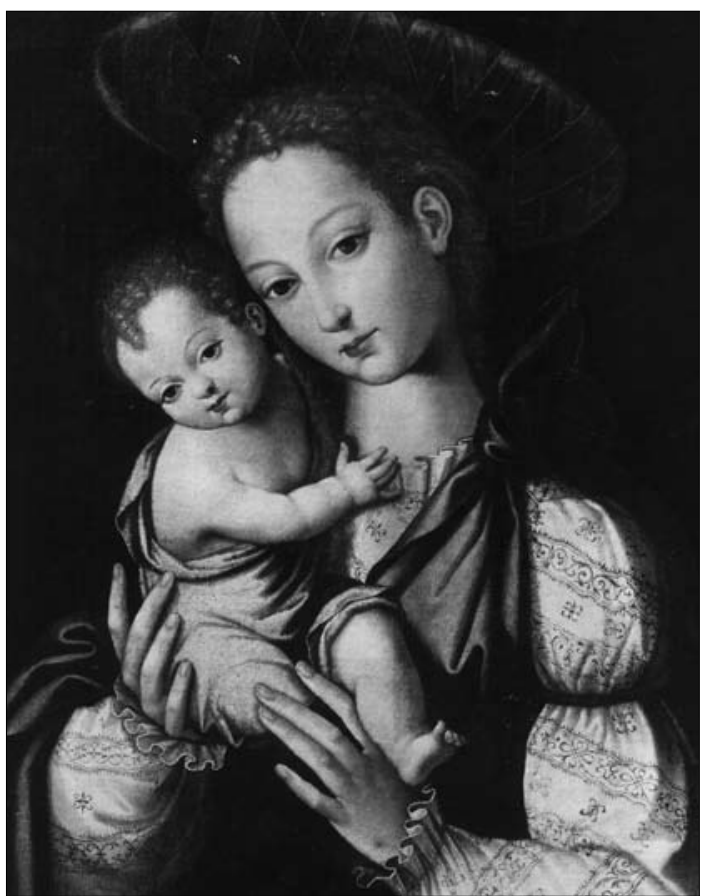

Fig. 23. Pedro Mata, Virgen del Sombrerero, Madrid, colección privada. 
Angulo la consideró de Morales cuando la vió ${ }^{38}$. Presenta como novedad que las cintas del sombrero no son lisas sino que van decoradas por un dibujo en forma de "ese" a cada lado de un eje central.

La citada versión de la colección barcelonesa de Balanzó (fig. 15) presenta la camisa de la Virgen estampada con finos bordados y, de la misma manera, aparece en la versión del Museo de Bellas Artes de Boston. Esta indumentaria bordada aparece en otra versión, si duda de un discípulo de Morales (fig. 23), que en el Archivo Fotográfico del C.S.I.C. figura en la colección Vives de Madrid, y en el archivo del Instituto Amatller de Barcelona, en la de Gómez Moreno, sin habernos sido posible conocer su localización exacta. Nos atrevemos a identificar a este discípulo de Morales con el portugués Pedro Mata ${ }^{39}$, por su similitud con obras suyas que se hallan en una colección privada de Lille (Francia) y en el Ayuntamiento de Trujillo (Cáceres).

El Asmolhean Museum de Oxford conserva otra Virgen del Sombrero en la que se funde este tema con el de la Virgen de la Leche interpretado por Morales.

Angulo citó un ejemplar que existió en la colección Lázaro Galdiano de Madrid y que debió venderse antes de 1927 puesto que no aparece en el catálogo de dicha colección de esa fecha. Considera Angulo que es una de las mejores versiones del tema de la Virgen del Sombrero pintada por Morales $^{40}$. A través de la fotografía podemos observar a la Virgen con el Niño tocada por el sombrero de cintas entrecruzadas. María mira de frente ofreciendo la novedad de mostrarnos un rostro de la Virgen diferente respecto a las restantes versiones y, también, un marco en el que la Virgen y el Niño se hallan protegidos a cada lado por cortinas y, en la parte superior, por una franja a modo de "bandeau" (fig. 24). La escenografía nos evoca un "Trampantojo a lo divino"41 y nos hace pensar en la posibilidad de que su destino fuera una capilla privada ¿la del obispo Ribera?, o ila del conde de Monteagudo? Respecto al modelo de la Virgen lo hemos localizado en la obra de Morales no precisamente en personajes protagonistas, sino entre las figuras de la comparsa del Nacimiento de la Virgen, del Prado y de la Sagrada Familia de la Hispanic Society de Nueva York. También existe cierto parecido con el modelo de la Virgen, que Solís localiza en la colección Adanero (fig. 16).

Cuando Solís estudia la Virgen de la colección Balanzó (fig. 15) señaló que fue expuesta en el Círculo Artístico de Lluc, en Barcelona en 1954, apareciendo con la denominación de $L a$ Divina Peregrina ${ }^{42}$. Rodríguez G. de Ceballos se decanta más por este sobrenombre que por el de La Divina Pastora propuesto por Angulo, sugiriendo que posiblemente la iconografía le fue dada a Morales por su comitente, el obispo don Juan de Ribera, para representar a la Virgen en su destierro a Egipto 43 .

Espigando por la poesía medieval dedicada a la Virgen observamos cómo desde Berceo va desapareciendo la rígida dignidad de María, dulcificándose y aproximándose a la devoción sencilla e íntima del creyente. En el Marqués de Santillana también hallamos vivas pinceladas en las que las alusiones a María aparecen ribeteadas de cierto paganismo renacentista.

En algunos poetas de este periodo existen versos que podrían ponerse en relación con la iconografía de la "Divina Pastora". Así Pedro de Santa Fe, en sus Loores de la Virgen María, la llama: ¡Oh bella, oh pastora! Pero ciertamente son más abundantes las alusiones al viaje a Egipto, entre los "Gozos de María". Hemos escogido dos ejemplos, uno de un poeta anónimo que dice:

\footnotetext{
38 Angulo, loc. cit. nota 1.

39 I. Mateo Gómez, "Dos nuevos Morales y obras de epígonos del pintor: Benito Sánchez Galindo y el Maestro de la Magdalena de Lille (Francia)", Archivo Español de Arte, 2003, p. 301-310. La indicación de que Pedro Mata es pintor portugués se la debó al profesor de la Universidad de Lisboa, Vitor Serrão.

40 Angulo, loc. cit. nota 1, la relaciona con una al parecer en la colección de los marqueses de Valderuey, y así consta en la foto localizada en el Institut Amatller de Barcelona.

41 A. E. PÉrez SÁNCHEZ, “Trampantojo "a lo divino”, Lecturas de Arte, 1992, p. 139-155.

42 Solís, loc. cit. nota 1, p. 173.

43 RodríGuez G. DE Ceballos, loc. cit. nota 2. También lo acepta F. Marías, loc. cit. nota. 4.
} 


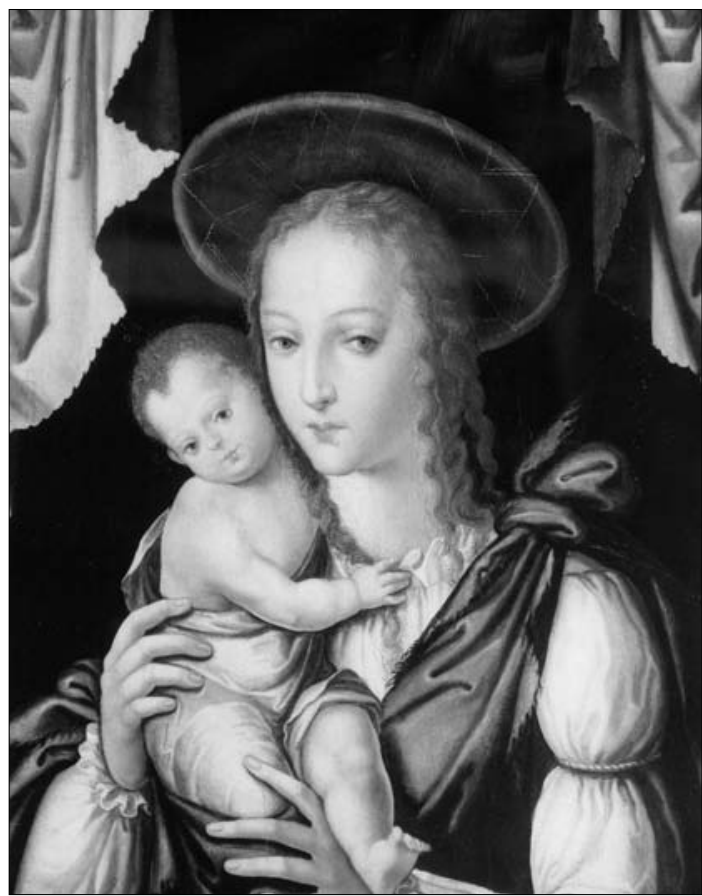

Fig. 24. L. de Morales, Virgen del Sombrerero, Madrid, colección Valderuey.

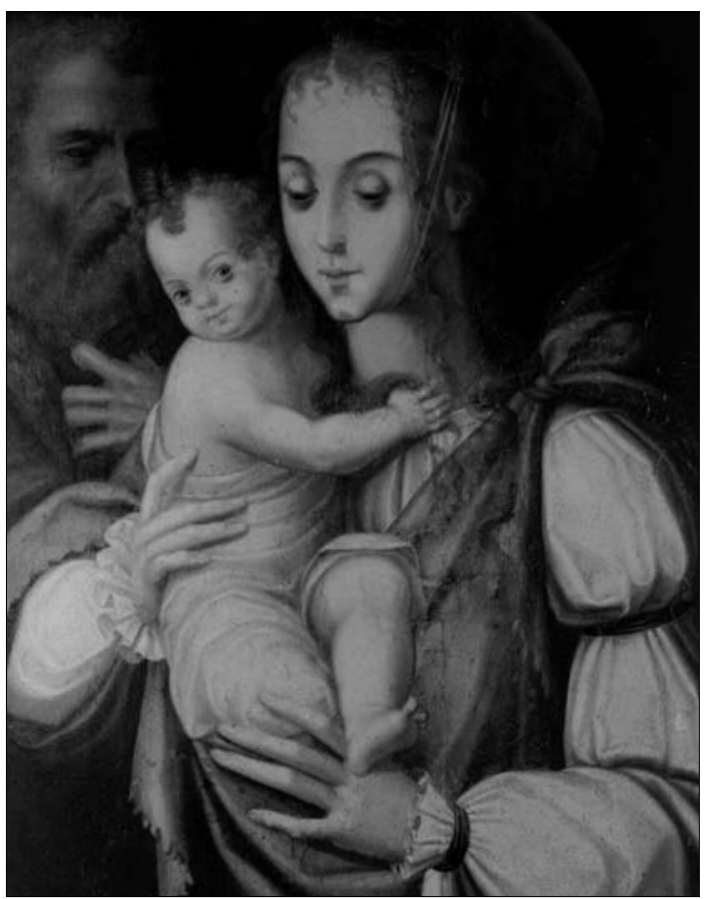

Fig. 25. L. de Morales, Virgen del Sombrero, Madrid, colección privada.

"El tu suyo gozo... /cuando dijo el ángel a José, tu esposo / e que se fuese a Egipto e sería muy goso..."; el otro, del Marqués de Santillana en Los Gozos de Nuestra Señora: "Gózate, nuestro dulzor, / por aquel gozo infinito / que te reveló en Egipto / el celeste embajador, / e la nueva deseada / de la paz; / gozáte, batalla e haz / de huestes bien ordenanzas" 44 .

Covarrubias, en El Tesoro de la Lengua Castellana o Española (1610) cuando trata el vocablo "gitano", relaciona el característico peregrinar de este pueblo, oriundo de Egipto, con la estancia en este país de "la Virgen nuestra Señora con su preciosísimo Hijo, por orden del Espíritu Santo según reveló al santo Joseph por el ángel" (Mateo, 2: Surge, et accipe puerum et matrem eius, et fue in Aegyptum). Precisamente hemos localizado una Sagrada Familia con la Virgen tocada con el Sombrero, de Morales, al parecer según consta en la foto del Instituto Amatller de Barcelona, en la colección Gómez Moreno de Madrid (fig. 25). Esta composición confirmaría la intención de Virgen Peregrina a Egipto, o de Virgen Gitana que con tanta prodigalidad realizó Morales. Peregrina de Portugal a España fue la emperatriz Isabel, cuyo retrato consideramos el origen de las restantes versiones de las Vírgenes del Sombrero de Morales.

El título de La Divina Peregrina, respondería al sentido religioso cercano propuesto por la poesía medieval, y su indumentaria exótica a la moda, el sentido que le dio Santa Teresa de no escatimarse la Virgen en ponerse bella para su Hijo.

${ }^{4}$ Antología de Poesía Mariana Medieval, Madrid, 1968. 